\title{
SAMLING OG SAMLERE
}

\author{
Introduktion
}

Engang fik Diderot en ny slåbrok. Da han tog den i brug, opdagede han, at hans pibe var sur, lænestolen slidt, og efterhånden sine øvrige ejendeles udtjenthed - han måtte, som tiden gik, have ny pibe, ny stol, nyt biblioteksbord, nye slippers, paryk, gardiner, gulvtæpper og så videre for at matche slåbrokken. En dag gik det op for ham, at hans gamle bibliotek ikke længere var sig selv - med alle de nylige udskiftninger havde det ændret karakter, Diderot var forsvundet fra sit eget herreværelse.

I denne sammenhæng er det ikke interessant, hvorvidt Diderots herreværelse faktisk indeholdt en samling eller blot en ophobning. Anekdoten tager fat i visse implikationer vedrørende måden, nyanskaffelser får konsekvenser for orden og nyfortolkning, og vedrørende et menneskes afhængighed af sine ting og hans fortolkning af tingenes samspil.

Muligvis er anekdoten usand, og måske klæber den netop til Diderot, fordi den klæder encyklopædisten, ikke desto mindre er dette Diderots syndrom at genfinde mange steder. Fænomenet samling balancerer hårfint mellem konsolidering og omkalfatring, uanset om en nyanskaffelse sker i institution eller i privat regi, er det altid en intrikat operation. Spillet mellem $\varnothing$ get kompleksitet og spredning: det er samlerens balancegang. Samlinger indebærer - i modsætning til ophobninger - afgrænsning, indlemmelse og udelukkelse.

\section{Samlingsantropologi}

Tidsskriftet Antropologi præsenterer med „Samling“ en række bidrag om samlinger og samlere. I det følgende vil mere generelle temaer ved samling blive slået an. I forbindelse med de mere overordnede overvejelser henvises specifikt til de af "Samlings“" tekster, der behandler nærliggende emner. Teksterne er langt rigere på perspektiver og emner, end det har været muligt at medtage her, så kun en af tonerne slås an for hver tekst.

Faget antropologi står samlingsbegrebet og samlerfiguren nær. Historisk er antropologi sammenvævet med såvel museernes materialsamlinger som ekspeditioners og feltarbejders sommerfuglesamlinger af mennesker og deres vaner og skikke, ritualer og my-ter. Antropologi og samling er i den forstand to sider af samme sag, hvad angår indsamlingspraksis. Også i den analytiske praksis, antropologer ofte betjener sig af, er faget for-bundet til samling: vi studerer gerne samfund som helheder af sociale organiseringer. 
Antropologer har desuden tit haft interesse for, hvordan (og hvorvidt) folk rundt om i ver-den samler, hvorved samleren som figur har været ombejlet. Al denne samling har smittet af på fagets form, og en vis samlingsamnesi i disse år har måske at gøre med en form-ændring i faget og i verden i øvrigt. Samling glider ud af fokus, efterhånden som nye og mere spredende strategier glider ind.

\section{Uden for institutionen}

I modsætning til museumsinstitutionen, der har oplysningsforpligtelse, kan private samlinger tillade sig ikke at have andet mål end den pågældende samling, fra frimærke- til plattesamlinger. Samlingsbegrebet står under stadig nytænkning, således for eksempel Per Højholt i sit Lynmuseum og Andy Warhol med sine Time Capsules. Per Højholt fortæller i „Lynmuseet“ fra Praxis 4, Lynmuseet og andre blindgyder (1982) om en Willy Lund fra Sig, der faktisk blev i stand til at indfange og opmagasinere lyn i en labyrint af blindgyder, han sindrigt havde udtænkt og opstillet til formålet. Om blot for en stund blev lyn holdt indespærret, naturbegivenheden samlet og kraften holdt fangen i en orden, indtil lynet slap ud igen. Andy Warhol forsøgte at oprette samlingsrum for konsum- og masseproducerede varer. Han shoppede for cirka 1 million dollars om året, og de ting, han købte, endte som regel i papkasser, en skøn pærevælling af uspecificeret junk. Når papkassen var fuld, blev den lukket og gemt som en Time Capsule. Som stærkt neurotisk kunstner var det Warhol magtpåliggende at få dagens impulsindkøb transformeret gennem samlerens systematik. Løsningen var Time Capsules, standard-flyttekasser, som fyldtes med ting i en vilkårlig orden. Warhol søgte at finde en ny måde at udsøge, indsamle og katalogisere sin samtids ting på. Lynsamleren Willy Lund samler på lyn, glimt, intense $\varnothing$ jeblikke og enestående begivenheder. Popkunstneren Andy Warhol samler derimod på industriproducerede replika, glimmer, kitsch og tingeltangel.

Forholdet til vore ejendele er mangfoldigt. Hjemmet tager flere bidragydere udgangspunkt i, men på vidt forskellig måde. J ting, Lene Otto viser erindringspotentialer i ting, og Orvar Löfgren tager os med til souvenirhylden. Andre skribenter tager udgangspunkt i personen, for eksempel Lars Kjarholm, hvis samling af lyde både er privat og åbner mod andre verdner, og Merete Kjar Christensen, der beretter om en vifte af forskelligartede samlinger. Gennem sin samling samler samleren ofte på minder og stemninger, som Nana Vaaben viser det $\mathrm{i}$ sin gennemgang af musikfans og deres autografjageri. Det er dog ikke altid tilfældet; samlere kan også være interesserede i ting, de ikke har nogen personlig tilknytning til jf. Anders Linde Laursens påpegning af det marked, der retter sig mod samlere og falbyder købte, ikke personligt indsamlede ting. Der samles også på data, som hos Hans Harrestrup Andersen, hvor fugle registreres og opleves, og på oplevelser, som det sker i Lars Holmbergs interview med en virtuel luftkaptajn.

\section{Museum}

Museernes opkomst hænger sammen med samlingers flytning fra de private raritetskabinetter til offentlige udstillingsinstitutioner. Museumsidéen og de private samlere har således fra starten været sammenvævede. Det giver Poul Mфrk et eksempel på i sin tekst 
om Kjersmeiers samling. Den engang så tætte forbindelse mellem offentligt museum og private samlere bliver dog stadigt svagere. Ansvaret er overgået til professionelle, inspektører og kuratorer, som Niels Fock blandt andet påpeger i sin tekst om rammer for samling.

De musealiserede samlinger viser udad. Etnografika henviser således til de miljøer, de er hentet i, mens kunstværker viser til de genrer, de spiller op ad. Samlingerne henviser også indad: De henviser til en formodning om, at der kan oversættes.

Som kulturelle spejl tjener museumsiscenesættelsen af samlinger til at reflektere det omgivende samfunds værdier, både i valg af genstande og valg af udstillingsmåder. Denne spejling er lige så vel til stede i de foranderlige egenskaber ved museumsinstitutionen, som i de træge. Nu, hvor museumsinstitutionens praksis og dens forhold til samlingerne er under for-andring, reflekterer den samfundsmæssige forandringer såvel som skift inden for institutionen.

\section{Betydning og inerti}

Hvilke faktorer bestemmer, hvordan en samling flyder sammen og bliver enestående? Selektive samlingsstrategier såvel som tilfældets spil, genstandenes interne relationer såvel som samlerens aftryk er elementer i konstellationen.

I offentlige samlinger er det tydeligt, men det findes også i private samlinger: samlingen indebærer en henvisning til en overordnet meta-diskurs, eller, som Frederik Stjernfelt formulerer det, den er underkastet et ,principielt blik“, en „transcendental modtager“ (1993:93,95). Også Krzysztof Pomian skriver om dette (Pomian 1990). Alle samlinger deler en reference til en usynlig verden udenfor tid og rum, pointerer Pomian (op.cit.:234). ${ }^{1}$ Det er dette punkt af fravær uden for samlingen selv, der giver samlingen betydning. Og det er dette punkt, der indebærer en vis træghed. Samlinger er en vigtig ingrediens i vort samfund, fordi tilfældigheder gennem dem fremstår som ordnede og meningsfulde, og fordi de har henvisningspotentiale til den transcendentale modtager, en henvisning, der indgiver betydning og sammenhæng. Det er også kasketten fra denne transcendentale modtager, man tager på, når man som samler vælger til og fra.

Valget og dets overordnede begrundelser er et væsentligt tema i Kirsten Raml $\downarrow v s$ artikel om flytninger af ting inden for institutionen Nationalmuseet (hvad skal udstilles?) og uden for, i privaten (hvad skal kasseres?). Vibeke Petersen overvejer ligeledes den overordnede henvisningsfigur gennem sin diskussion af udstillingsmåder som underlagt forskellige tiders fortolkninger. Samtidig med, at vi lader os guide af et principielt blik på samlingen (i valget, gennem udstillingen), giver situation, person og konkret ramme også sit til, hvilke valg, der træffes. Det viser Rolf Gilbergs indsamling af et mongolsk telt, her inddrages personen. I Espen Wahles artikel diskuteres forskellige strategier for indsamling gennem congolesiske eksempler, her inddrages de skiftende museale strategier.

Hvor lidt skal der til, før en samling er påbegyndt? Hvornår bliver en tingfinder en samler? Hvor stor skal en samling være, for at kunne sætte dagsorden for andre samlinger? Kan man opbygge den komplette samling? Den slags afgrænsninger har at gøre med samlingens abstrakte betydning (henvisningen til det, der er større end den selv), og den inerti, den er underlagt i sin konkrete væren (tid og ting). 


\section{Dekonstruktion, repræsentation og oplevelse}

Store dele af de humanistiske fag, efterhånden også antropologi, har siden 1970'erne været under dekonstruktion. Efter en samler kommer en spreder, og dekonstruktion betyder også spredning, dekonstruktion dekonstruerer netop enhver samling. Konstruktion og dekonstruktion er to sider af samme sag: socialkonstruktivisme hviler på dekonstruktive metoder, og dekonstruktion på en forståelse af omverdenen som konstrueret. Den spredende metode (analyse) har altid fandtes side om side med den samlende metode (syntese), det er der ikke noget nyt i. Men det store fokus på ,de-“, det mindre på ,konstruktion" har betydet en forflyttelse af nogle positioner i det antropologiske landskab, også ,samling“. Samling angår dog måden, vi tænker både den verden og de ting, der omgiver os, og følgelig måden, vi negerer og dekonstruerer disse tankeformer. Spillet mellem konstruktion og dekonstruktion findes i de mere overordnede videnskabsteore-tiske overvejelser på meget forskellig vis. Hanne Vebers bidrag fokuserer på kategorien jæger-samler (egentlig samler-jæger) fra et dekonstruktivt perspektiv, Jens Paaske fortæller om implikationerne ved og fremkomsten af det periodiske system og andre store samlinger i fysikken, Kirsten Winther Jørgensen undersøger betingelserne for zoologiens opkomst, for den første store videnskabelige taksonomisering af dyr, og Bryan Cleal overvejer virtuelle samlinger og sociale fællesskaber.

I 1980'ernes repræsentationsdebat bliver samling, museer og genstande tematiseret. Det bliver pointeret, at samlinger, udstillinger, ting altid er for nogen, altid er at forstå i kontekst. Omgangen med ting og samling illustrerer på glimrende vis en hermeneutisk tilgang til omverdenen, omdrejningspunktet for repræsentationsdebatten; samtidig er der tale om en refrasering af dekonstruktive pointer og tænkemåder. Dette tankelandskab blev visualiseret på Nationalmuseets særudstilling Museum Europa (1993). Tidsskriftet Antropologi bidrog til debatten med „Ordentlige ting“ (1990).

I 1990'erne bliver overvejelserne efterhånden mere praktiske. Samling havde hørt hjemme i såvel universiteter som museer, men flytter efterhånden ind i museerne, i hvis gange den af og til og nogle steder forsvinder. Det interessante bliver stadigt oftere, hvorledes museerne og deres samlinger kan give brugerne en oplevelse. Der er i den forbindelse gjort brug af virtuelle udstillinger, interaktivitet og andre måder at udstille på i de ofte nye og anderledes tilbygninger eller ombygninger. Dette anvendte fokus på samlingerne, giv-dem-en-oplevelse-fokuset, giver anledning til to bevægelser: fra at have været målet, bliver samlingerne i nogle tilfælde museernes middel til et nyt mål, oplevelse. Det betyder, at de særegne, unikke steder, som museerne ofte var, står i fare for at blive til globale replika: ethvert kunstmuseum sin Warhol, Beuys, Picasso. Der samles, som i lynmuseet, på intense øjeblikke. Derved normaliseres det ekstraordinære. Alt dette fører i nogle tilfælde til blindhed i forhold til selve samlingen og somme tider også i forhold til det repræsentative fokus på samlinger, de-betyder-noget-for-nogen.

Fra antropologisk side er der holdt forbindelse til temaer i omegnen af samling de seneste år, men den tidligere så nære kontakt mellem antropologi og samling har ikke været særlig vital. Dog er temakredsen for tiden taget op igen. Folk Journal of the Danish Eth-nographic Societys ganske nye udgivelse „Exhibiting Objects. Collections in Policy and Practice"(2001) og Jordens Folks temanummer om Etnografisk Samling fra 1999 (begge i forbindelse med Etnografisk Samlings 150-års jubilæum) er, som „Samling“ eksempler herpå.

Samling er en evergreen, der i nogle år har fristet en stille tilværelse. Når samling har 
været glemt, og repræsentationsdebatten glider bort fra de materielle genstande, mens museerne fokuserer på oplevelser, kunne man se det som tegn på, at der er nye konstellationer på vej, hvad angår måderne, samling og samfund forbinder sig til hinanden. De noget tilsandede pipelines mellem antropologi og samling og nogle steder efterhånden også mellem institution og samling er måske ved at ændre deres løb.

\section{Her \& nu}

Det var erfaringen fra repræsentationsdebatten, at enhver samling indgår i et net af fortolkninger, men på hvilke måder? Den hermeneutiske tilgang kan i dag anvendes, idet den forstås som en præmis snarere end pointen.

1990'erne viste, hvad der kunne ske, hvis man kontekstualiserede samlingerne væk fra sig selv, hvis man glemte „varen“ for „kunden“ og „oplevelsen“. Skal det være en præfabrikeret „oplevelse“ at erfare en samling? Der dukker straks andre spørgsmål op som for eksempel: Er der forskel på de valg, der bliver truffet som baggrund for private og offentlige samlinger? Kan der overhovedet skelnes? Hvorledes spiller den rumlige organisering ind? Hvordan har genstandes erindringspotentiale betydning for samlere? Hvorledes forbinder konservering og kassation sig til hinanden? Og hvad med destruktion? Inger Sjфrslev fortæller om emner, der angår dette felt, i sin artikel om en samlings transformation, dens destruktion og rekonstruktion.

Skellet mellem offentlige museumssamlinger og private, ja, personlige samlinger bliver stadigt tydeligere, efterhånden som samlingerne forsvinder fra museerne i en implosion af tilrettelæggelse. De private samlinger træder tydeligere frem, i takt med at nogle af de offentlige bliver mere strømlinede og derved utydelige. Torkil Funder giver et eksempel på et privat museum med en egen karakter og frihed, Siam Museet i Ebeltoft. Der er en tendens til, at samling som fænomen bliver mere synlig i det private regi, oplevelsen i det offentlige. Det offentlige rum er under annullering, bliver det ofte spået, og det er måske denne tendens, vi er vidne til i samlingsregi. De passionerede samlinger, de anderledes steder, de private rum, der dukker frem med fornyet styrke, efterhånden som de offentlige annulleres, bliver nye foki, derhjemme i skuffen, i gallerierne eller der, hvor det særegne stadig får plads i musealt regi. Mark Vacher skriver om sådan et museum på Saltholm. Den decentrale tendens har sine fordele: up to date-udgaver af kunstkammerets kuriositeter finder atter vej som alternativ til de strømlinede pakkeløsninger.

\section{Levende døde}

Indsamling, registrering, konservering, forskning og formidling, disse ved lov vedtagne krav til museer er ofte (om end i svingende grad) frivillige ingredienser i ikke-museale samlinger. Det er handlinger, der fører tingen fra det flux af liv og omskiftelighed, den befandt sig i, til sin endestation. På den måde er samlingen dødelig for sine ting. Indsamlede æg får andre repræsentative roller i samlingen end i reden. Samtidig forvandles de levende æg til døde skaller. I bekendtgørelse om æggesamlinger gøres de derefter, og som tredje endestation for æggene, ulovlige, hvilket Trine Jørgensen viser i sit bidrag. Ting, der er endt i den dødelige samling, kan dog leve et liv som levende døde her: 
om-verdenens og samlerens fortolkning af dem skifter over tid. Tid som rum, kategorise-ringsmetoder som kontekster, alt dette gør samlingen foranderlig, og giver genstandene nye roller at spille.

På Rosenborg Slot var jeg ude for en hændelse, som antydede et forhold mellem samling og gengangeri: „Er der spøgelser på Rosenborg?“ spurgte jeg en kustode, som var vaks ved havelågen: „Nej, jeg har ikke set ét eneste spøgelse i de 300 år, jeg har været på dette sted," svarede han og forsvandt bag nogle montrer.

Jeg følte mig udsat for en mangfoldighed af spøgeri, for bortset fra, at kustoden nok spøgte, forekom pludselig alle museumsgenstandene så stærkt løsrevet fra deres gængse kontekst, at slottet virkede som spækket med håndgribelige spøgelser. I 1997 var det min påstand, at tingene bliver til gespenster gennem musealisering (Raahauge 1997). Men måske behøves ikke så stærke kræfter: muligvis er selve indlemmelsen af en genstand i en samling tilstrækkeligt til gespenstificering. Måske er endda samlerens begær i sig selv nok til at gøre tingen til offer for en samling.

Etnografiske museers verdensspejl, kunstmuseers åndsspejl, og alle de andre museers og samlingers forskellige spejle justerer sig hele tiden, så de kan spejle den tid og det samfund, de er en del af. Mikael B $\phi g h$ Rasmussen giver et eksempel på en sådan spejling i sin receptionshistoriske gennemgang af J. F. Willumsens Gamle Samling. Samtidig med at genstandene afsjæles, får samlingen (paradoksalt nok) liv: Den bliver uregerlig, mere og mere, faktisk, efterhånden som genstandene hober sig op inden for dens idés grænse. Der kan ske det, at samlingen vokser ud over alle bredder, den kan vokse sig for stor til at være en samling. En sådan hypertrofi kan betyde, at samlingen holder op med at være en samling og bliver til en uforståelig hoben ting. Den kan også betyde, at samlingen opsplittes i to eller flere samlinger. Omvendt kan flere samlinger pludselig samles til én, som det sker i større museer, når de opkøber eller får doneret samlinger til den STORE samling. Samlinger kan eksplodere og blive til mange eller implodere og blive til ingen, eller de kan elastisk indoptage underkategorier af samlinger i sig.

\section{Believe-it-or-not}

For ikke så længe siden var jeg i den københavnske udgave af Believe-it-or-not-museet lige ved Rådhuspladsen. Her er store oplevelser i vente for den besøgende. Faktisk er ordet „oplevelse“ her på sin plads. At man så befinder sig ved montrer, hvor man kan se fakta og oplysninger, er en anden sag. De står lige ved siden af montrer, der leger med de oplysninger, de er fulde af - muligheden for fup, historier, løgn er en del af rammen. Her er der rum for vidtløftigheder, fusentasterier og fantasmer.

Believe-it-or-not-museet befinder sig på grænsen. Det er en franchised global gesjæft, som samtidig har unika, der relaterer sig til deres lokalitet (for eksempel et værk, cirka 100 x $150 \mathrm{~cm}$, forestillende dronning Magrethe omtrent i naturlig størrelse, udført som maleri med lommeuld af forskellig farve). Det er en replikeret model, som samtidig er fuld af unika (for eksempel Taj Mahal bygget af tændstikker). Det befinder sig mellem banal kedsomhed og hysterisk eksotisme. Det stiller samleren, en excentriker ved navn Ripley, i centrum gennem filmoptagelser af ham i de varme lande, opstillinger af hans kontor med mere, og peger således i al sin sluddervornhed også på en grundlægger, en berettigelse for hele showet. Belive-it-or-not-museet kan tillade sig at tone rent flag som 
kommerciel oplevelsesgenerator og også tænke kontekstuelt, indramme tingene på tvetydige måder, lege med fortolkningerne hos de forskellige gæster og være en interaktiv oplevelse.

Believe-it-or-not-museet mimer (og persiflerer måske endda) desuden de museer, vi kender til bevidstløshed, de replikerede, globale institutioner. Believe-it-or-not-museet kan føre en linie tilbage til raritetskabinettet. Det er dette slægtskab, eller snarere, den fælles glæde, de to har ved verdens forunderlighed, dens mysterier og overraskelser, der gør, at Believe-it-or-not-museet eksisterer ikke blot merkantilt, men også som museumsgenre, der dyrker det ekstraordinære.

Gennemkommercialiseret, stjernedyrt, prædesignet, replikeret, privatiseret rum er, hvad Believe-it-or-not-museet kan tilbyde. Det er et typisk barn af tiden. Men det griber også tilbage til tidligere tiders glæde ved det eksotiske og anderledes, forbløffelsen ved verdens mærkværdigheder og grotesker, et af de drivende incitamenter for samlere (og forhåbentlig også antropologer!). Her kan det lykkes, fordi konteksten er klar: believe it or not.

\title{
Samling
}

Med „Samling“ lagde redaktionen op til en undersøgelse af samling og samlere i dag, perspektiveret på flere ledder. Bidragene til „Samling“ krydser på tværs af diverse skel og kategorier; emnet overvejes og eksemplificeres på nye måder. Det var lige netop det, redaktionen håbede på. Vi fik, hvad vi bad om og mere til. „Samling“ indeholder 16 artikler og et interview, to reviews og fem anmeldelser. Indlagt i nummerets artikelfølge er de grå sider og de glittede sider. De grå sider, enqueten med syv bidrag, gjaldt, ,grænser for samling“. „Man kan nemt genkende en samling, når man ser en, men hvad er det egentlig, der adskiller en samling fra en simpel ophobning?“", spurgte vi de indbudte skribenter. Enquetens egen afgrænsning er, at den kun blev sendt ud til antropologer. ${ }^{2}$ Artiklernes skribenter, derimod, er en fagligt mere spredt gruppe. De glittede sider er påtrykt illustrationer til visse af artiklerne, så man må følge henvisningerne mellem tekst og illustration for at finde vej. Og så til sagen!

\section{Noter}

1. Tak til Kirsten Winther Jørgensen for henvisningen til denne vigtige passus hos Krzysztof Pomian.

2. Redaktører af enqueten er Kirsten Winther Jørgensen og Kirsten Marie Raahauge.

\author{
Litteratur \\ Braae, Christel, Michael Harbsmeier \& Inger Sjørslev (eds.) \\ $2001 \quad$ Exhibiting Objects. Museum Collections in Policy and Practice. Folk Journal of the Danish \\ Højholt, Per \\ Ethnographic Society 43. \\ 1982 \\ Lynmuseet. Praxis 4. Lynmuseet og andre blindgyder. København: Gyldendal.
}


Jordens Folk

1999 Etnografisk Samling - 150 år. Dansk Etnografisk Forening.

Pomian, Krzysztof

1990 Collectors and Curiosities. Paris and Venice, 1500-1800. Cambridge: Polity Press.

Raahauge, Kirsten Marie

1997 Museumsrum. Tidsskriftet Antropologi 35/36:199-206.

Sjørslev, Inger et al.

$1990 \quad$ Ordentlige ting. Tidsskriftet Antropologi 21/22.

Stjernfelt, Frederik

1993 Trines dusk og løvhytten - eller: det imaginære museum på nye æventyr. Den jyske Historiker 64:91-101.

Wagner, Michael F. et al.

1993 Museum Europa - Om tingenes orden. Den jyske Historiker 64. 